\title{
'ANOTHER WAY OF NAMING ELSEWHERE': TRANSNATIONAL AND HEMISPHERIC STORIES BY SOME CANADIAN AND ARGENTINIAN AUTHORS
}

\author{
María Jesús Llarena-Ascanio \\ Universidad de La Laguna
}

\begin{abstract}
Transnational and gothic discourses have for some time been paired in critical invocations of the unhomely or spectral legacies of imperialism and globalization. This legacy, which appears in the form of unresolved memory traces and occluded histories resulting from diasporic migration is readily figured as an ostranenie which haunts the characters of some Argentinian and Canadian storytelling from within and without. The writers of these stories are first or second generation migrants who developed their writing career in the host country. This essay tries to analyse these transnational stories which we will call hemispheric and which bear some resemblance in Canadian and Argentinian writing, for different political and traumatic reasons, in their cinematic deployment of the homeSpace horror, childhood memories and physical and psychological boundaries which chain us to our ancestors' memories.
\end{abstract}

KEYwORDs: identity, displacement, memory, hemispheric stories, transnationalism, Canada, Argentina.

\section{'OTRA FORMA DE DENOMINAR A CUALQUIER PARTE': HISTORIAS TRANSNACIONALES Y HEMISFÉRICAS DE AUTORES CANADIENSES Y ARGENTINOS}

\section{RESUMEN}

Los discursos transnacionales y góticos han ido de la mano en los últimos estudios críticos sobre el transterrado o el legado espectral del imperialismo y la globalización. Este legado, que aparece en los rastros perdidos de la memoria y las historias interrumpidas que resultan del viaje migratorio, se muestra en la literatura canadiense y argentina con extrañamiento y defamiliarización. Estos escritores desplazados desarrollaron sus carreras en el país de acogida y escriben historias transnacionales que llamaremos hemisféricas y que muestran cierto paralelismo en estos dos países por diferentes razones políticas y traumáticas a través de un desarrollo cinematográfico del horror en el espacio doméstico, los recuerdos de la niñez, y las fronteras físicas y psicológicas que nos impiden liberarnos de la memoria de nuestros padres y abuelos.

Palabras Clave: identidad, desplazamiento, memoria, relatos hemisféricos, transnacionalidad, Canadá, Argentina.

DOI: https://doi.org/10.25145/j.recaesin.2019.78.04

Revista Canaria de Estudios Ingleses, 78; April 2019, pp. 55-73; ISSN: e-2530-8335 
During the last decade of the twentieth century, many notable changes took place in both Canadian and Argentinian literatures. This was a period of opening from what had been an emphasis on writers of the so-called canon to what used to be the Other, that is, the migrant who left the political turmoil in Argentina, like Clara Obligado, Sylvia Molloy, or Rodrigo Fresán, and the immigrant to Canada from countries other than the British Isles or Ireland. This change began in the 1980 s, and certainly in the 1990s such writers began to achieve the recognition long due to them, not only with the general public in terms of book sales, but also by winning major literary awards. ${ }^{1}$ By the end of the 1990s the idea of texts being set in other countries had become something of a norm. These writers would not have been what they are today without having migrated. The migrant narrative had arrived and became a major force in both literatures.

Michael Ondaatje, Shyam Selvadurai, Rohinton Mistry, Madeleine Thien, Hiromi Goto, Shani Mootoo, David Chariandy and Kim Thúy were generally residents in the new countries and they could no longer be grouped together as having one discourse; the voices were as varied as the styles they employed. This essay will try to analyse some transnational characteristics that define these writings which we will call hemispheric, drawing on Siemerling and Phillips Casteel's groundbreaking collection Canada and Its Americas: Transnational Navigations (2010). In the last few decades, Canadian literature has been catapulted onto the global stage, gaining international readership and recognition. Canada and Its Americas challenges the convention that the study of this literature should be limited to its place within national borders, arguing that these works should be examined from their perspective of their place and influence within the Americas as a whole. This concept expands the horizons of American literatures, and suggests alternative approaches to models centred on the United States, and analyzes the risks and benefits of hemispheric approaches to Canada. Revealing the connections among a broad range of Canadian, Latin American, Caribbean and diasporic literatures, we believe such writing can be successfully integrated into an emerging area of literary enquiry. Globality thus reveals exciting new ways for thinking about transnationalism, regionalism, border cultures, and the literatures they produce. We will try to see the hemispheric connec-

${ }^{1}$ Some of the most important literary awards have gone to Michael Ondaatje, Booker Prize and Governor General's Award (1992; 2000), Giller Prize (2000); Shyam Selvadurai, Books in Canada First Novel Award, Lambda Literary Award (1994); or Hiromi Goto, Commonwealth Writers Prize (1994). Shani Mootoo was shortliststed for the Giller Prize (1997; 2004), whereas Rohinton Mistry won the Governor General's Award (1991), and Giller Prize (1995). Madeleine Thien, in turn, won the Governor General's Award and Giller Prize (2016), Kim Thúy, the Governor General's Award (2010), and David Chariandy was shortlisted for the Governor General's Award 2007, Commonwealth Writers' Prize (2008), City of Toronto Book Award (2008). Valeria Correa-Fiz won the Claudio Rodríguez Prize (2016); Ariana Harwicz, longlisted, Man Booker International (2018); Marcelo Luján, Santa Cruz de Tenerife (2016), Dashiell Hammett (2016); Andrés Neuman, Alfaguara (2009), shortlisted, IMPAC Dublin Literary Award (2014) and the Independent Foreign Fiction Prize (2013); Samanta Schweblin, Tigre Juan (2015), Ribera del Duero (2015), and shortlisted Man Booker International (2017); Clara Obligado, Lumen (1996), Setenil (2012), and Juan March (2015). 
tions to some Argentinian writers who left their native land for political or familiar reasons, such as Sylvia Molloy, Clara Obligado, Andrés Neuman, Samanta Schweblin, Valeria Correa-Fiz, Florencia del Campo, Ariana Harwicz or Marcelo Luján.

Aspects of globality, ambivalence, liminality, mimicry, boundary dissolution and epistemological destabilization characterize the negotiations that occur in Canadian and Argentinian locations, which seem to invite gothic figuration, not only in terms of the monstrous or grotesque, but also in terms of subjective and national interiority and unsettlement (Sugars and Turcotte, Introduction viii). In many of these works there is an aura of unresolved and unbroachable guilt as though the traumas of the past have not been thoroughly assimilated. The uncanny, which is linked to the paradox of home and unhomeliness, is one of these gothic manifestations. These tropes may be used to convey the ways in which Canadian and Argentinian national projects are inherently haunted, as a mediation of forgotten histories or to initiate forms of cultural mourning. ${ }^{2}$ Paul Gilroy's conceptualizing of the black Atlantic has been particularly useful to relate to the work of Latin American theorists to produce a global and hemispheric approach to the literatures and cultures of the Americas. There is a culture that is not specifically African, American, Caribbean, or British, but all of these at once, a black Atlantic culture whose themes and techniques transcend ethnicity and nationality to produce something globally unremarked before. This mode of storytelling is preoccupied with the fringes, the unspoken, the peripheral, and the cast aside. It is populated with monsters and outcasts, villains and victims, specters and the living dead. It enacts and thematizes ambivalence, offering a possibility of mediations into real-world politics, since it "exposes the Gothic reality of modern identity, and by failing to represent an adequate solution it forces its readers to address them in real life, thus (ideally) using literature to encourage social change" (Sugars and Turcotte xv). This is especially clear in examples of ecofeminism and the uncanny, which materialize and familiarize haunting and trauma by merging the real world with the otherworldly. We will see how there is a Canadian and Argentinian articulation of a transnational revisioning of their traumatic histories, to embrace their national meta-narratives, to articulate globality and to write back to nationalist paradigms in order to challenge dominant literary, political, and social narratives. Since the 1990s, the discourses of multiculturalism, border studies, diaspora studies, and cosmopolitanism have been invoked in various ways to help underwrite a transnational approach to literary studies (see Jay). Over the last twenty years, gender has become a crucial object of analysis in the study of globalization. Every culture is shaped by other cultures, and agency has more to do with the intelligent and imaginative negotiation of the cross-cultural, on the one hand, and variously enabled and circumscribed by gen-

2 In Specters of Marx, Jacques Derrida talks about a notion of hauntology that may replace ontology in that it defines a process of return of suppressed knowledge (hence the tropes of spectres/ ghosts) that constantly suspends ontological certainties (10). Hauntology is tied to memory and historicity, on one end, and to a notion of future justice, on the other, for the project involves the recognition of a politics of memory that can effect social and historical transformation (Darias-Beautell 402). 
der, on the other. We do want to advocate other approaches based on a global and hemispheric reframing of the origins, production, and concerns to look closely at how the production has increasingly become transnational, and how it has become engaged with a set of issues related to globalization (Jay xi). Border studies in the Americas can thus provide a model for how to remap the geographical spaces of literary and cultural studies. Paul Jay links Junot Díaz's The Brief Wondrous Life of Oscar Wao (2008) to the transnational turn in English in order to underscore how it deals with a range of issues about mobility and displacement and thus shift the reader between multiple locations, engaging a new model of migration characterized by that back-and-forth moving of people across borders, as Vassanji's or Mistry's, at once insisting on the importance of location and deterritorializing the aspects in which their characters operate (Jay xi). Colonialism and dictatorship in the Americas are linked to masculinity and storytelling, a counterdiscourse that these Argentinian and Canadian authors' narratives use to undo that power through critical and fictional texts that complicate simple national narratives and narrow myths about purity and belonging.

There is a shift of emphasis in contemporary diasporic writing, for many new texts are set in the native land and feature reversed migration back to a home place by a Westernized protagonist who does not so much want to return home as to write back home. This is the case not only of a first generation of diasporic writers such as Ondaatje, Mistry, Obligado or Molloy, but also of those who have published in the 2000s, such as Goto, Mootoo, Thien, Chariandy, Thúy, Neuman, Schweblin, Correa-Fiz, del Campo, Harwicz or Luján. They provide powerful counter-discursive accounts of the Canadian and Argentinian metanarrative which will probably reassess the nations's remembered past through gothic accounts of memory loss, trauma, and testimony, as in Shani Mootoo's Cereus Blooms at Night (1998), Kim Thuy's Mân (2013), Madeleine Thien's Simple Recipes (2001), David Chariandy's Soucouyant (2007), Schweblin's Siete casas vacias (2015), Fever Dream (2014), or Marcelo Luján's Subsuelo (2016). We have turned our attention to fluid collectivities that attend to variously "glocal" locations (Sugars and Ty 10), particularly in the context of transnational displacement, violence and amnesia. These authors demonstrate that the divide between remembering and identity is not so easily established, as they consider, for example, the theme of memory loss and Alzheimer's disease a way of exploring a larger societal and cultural concern with the uncertain boundaries between memory, history, and selfhood.

Canadian diasporic writing is anew within the context of a new inter-American transborder integration, which has substantially changed the field of identity politics, the very concept of ethnicity and the need for its redefinition, as well as the various cultural/literary practices of a collective and individual dynamic identity construction (Zorc-Maver and Maver 119). This imagined frontera has enabled many writers such as Clara Obligado in her stories El libro de los viajes equivocados (2011) or Salsa (2002), to see their own culture from the point of view of heterogeneity and messiness, subalternity and hybridity, in order to focus on the conceptual possibilities related to borders, border-crossings, and borderlands, frequently not even a geographical but an imaginary space of contact. It is really the border 
within ourselves that must be crossed and embraced, for maps are metaphors and not the territory.

The subsequent reterritorialization of hemispheric Americans seems to depict, however, people lost between countries and languages, in their complex citizenship caught between the desire to run away and to belong: "En aquellos años uno se marchaba sin la esperanza de volver. La única promesa era no olvidar" (Thúy 47). These migrant writers share culture, memory and repertoire of linguistic signs, and incorporate a hemispheric awareness into their poetics. This contextual broadening is always enriching in the treatment of the homeSpace which functions as both a site of identity construction and performance, and a site of disruption, resistance, and alienation (Brydon 6). This hemispheric turn taking place in the 1990s has tended to pay attention to minority and marginalized discourses, so American literatures and cultures become plural and multilingual. The writers we focus on may contribute to the possibilities of rethinking a hemispheric approach to the Americas. The border with the U.S. making the point that national boundaries are a consequence of settlement and not primordial facts of thinking and belonging (Siemerling and Phillips Casteel 16).

This diasporic experience can be public or private, where the writer plays a conscious role of mythmaker and folk historian who preserves the collective tradition. In Ondaatje's Running in the Family (1982) the writer returns to Sri Lanka and encounters his past, evoked either in specific historical events, as in Neuman's Una Vez Argentina (2014) or Piglia's Los Diarios de Emilio Renzi (2015b), or in evocative scenery and imagery, as in Mistry's Tales from Firozsha Baag (1992), Chariandy's Soucouyant (2007), or Obligado's Los viajes equivocados (2011). These writers loosely hang together but as segments of an unfinished jigsaw puzzle: not quite fitting but belonging together as they complement each other in time and space, and together they span the literary record of a collective experience (Vassanji 63). These remains of the past are also frequently assembled by the imagination to form a new, and kaleidoscopic design which, as Homi Bhabha states, "does not merely recall the past as social cause or aesthetic precedent; it renews the past, refiguring it as a contingent 'in-between' space, that innovates and interrupts the performance of the present" (Location 7). The negotiation of place and the attempt to re-create a home through a fragmented memory is uncertain, "la identidad personal se basa en la memoria [...] no hay memoria propia ni recuerdo verdadero, todo pasado es incierto y es impersonal" (Piglia Formas breves $50-51$ ). . For these writers the intersection of language and place creates, therefore, an "unfixed self" (Mishra 154), where the landscape against which the 'I' can authentically figure is at stake (Warley 22). Some of the themes in texts such as Ondaatje's Anil's Ghost (2000), Selvadurai's Funny Boy (1994), or Neuman's Fractura (2018) arise from the cultural shock

3 See the Introduction to Los diarios de Emilio Renzi. Los años felices. Piglia here develops this idea of a non-existing narrator, all depends on the reader's belief in what he or she is reading, is it true or false, real or imaginary? Is the contemporary writer a spy, a chronicler or a witness? 
of return to a place and language almost forgotten, to construct meaning for the survivors of catastrophe, "those who were slammed and stained by violence lost the power of language and logic. It was the way to abandon emotion, a last protection for the self" (Anil's Ghost 55, 56). These are novels of terrorism, as they create a narrative structure that replicates the experience of terror, ask the reader to engage in an act of reconstruction, and piece together stories and psychologies. In Running in the Family, Soucouyant and Una vez Argentina several moments come into being when the impression of an objective world encounters the expression of the internal world of the narrator. Both Anil's Ghost and Fractura provide an examination of identity reflective of the cultural clashes that are an inevitable consequence of such an interweaving of nationalities, histories and border divisions. Both explore the notion of nationality as a construct and examine the role played by syncretism and hybridity incorporating and transgressing boundaries in a way that invites interrogation from a transnational perspective. The political struggles mirror their personal ones as "[o]ne can die from private woes as easily as from public ones" (Anil's Ghost 202).

Hemispheric storytelling uses its own resources to turn displacement and ostranenie into an ordinary family tragedy as in Fever Dream, Subsuelo or Simple Recipes, developing an aesthetics of the everyday that is based on the limited, confused viewpoint of an ordinary narrator-protagonist, as in Mân, Viajes equivocados or en breve cárcel (1981). Sometimes everyday objects reflect a far-away reality, as in Siete casas vacías or La condición animal (2016), even with the narrator's search for an adequate metaphor to encompass the complexity of his or her personal life in a global context, as in Running in the Family, Soucouyant, Funny Boy, Una vez Argentina or Fractura. Another approach is ecocriticism, an interpretive framework whose focus on geography and ecology also serves to problematize geopolitical boundaries in Precoz (2016), Fever Dream and Fractura. The result is experimental beauty, as in Neuman's words:

Me es hermoso el desgarro porque une las orillas, nos concentra en desdoblarnos siempre para poder ser uno.

[...] Necesario el desgarro, porque renuncia a hundirse

pero ama los pozos

y nos tiende sus manos como dos hemisferios.

Con el pulso ambidiestro

navego celebrando los puntos cardinales

que mudarán mi origen,

y sucede el naufragio porque debe

y la vida es el barco

y yo soy el ahogado y el mismo que me salva. ("Las Orillas" 73)

These literary attempts at national remembering are important national cultural interventions: "Personajes imaginando lo que recuerdan, recordando lo que imaginan. ¿Es verdad? ¿Es mentira? No son esas las preguntas" (Una vez Argentina 23). The question, and answer, lies, for Drucaroff, deeply rooted in a number of 
"thematic stains" (488) when dealing with displacement, the disappeared, the "filicide imaginary," or the false memory in their endless search for footprints that unveil their recent past traumas. Argentina, like Canada, is a country in which a certain portion of its cultural production is exile in nature. Many significant works of Argentine literature have been written in exile and published originally in exile, where they have shown the degradation of culture and society caused by the grim facts of political life in Argentina under military authoritarianism. Short stories by Obligado, Fresán or Neuman, have all helped to disrupt the silence that had previously prevented an international awareness and a public denunciation of such a tragic period of Argentine history. They are linked together by commonly denouncing the silence by alluding to nameless characters who must sift fantasy from reality. These wandering figures searching for their identity represent the nature and extent of human suffering in a world that denies them their very humanity (Lubarsky 41-42).

What Drucaroff terms "New Argentinian Narrative" (95) analyses the renaming of the silenced trauma of the last military dictatorship which was banished in the new generation of writers born in the 60s and 70s. Elsa Drucaroff names them "prisoners" to define their position against their previous generations, which has made them escape from a secluded and constrained social discourse to become something new, "una narrativa verdaderamente nueva y, en muchos casos, valiosa, además de un movimiento dinámico y crítico de la sociedad argentina" (185). The last thirty years of Argentinian writing renames memory, and finds, either thematically or formally, beauty in the naming from elsewhere, that is, it hides its political and traumatic scars being elusive, elliptical, amphibian, but with an intense historical and social consciousness as Neuman affirms ("Narrativa" 3). Their writing has its own way of looking at the world, of renaming the Argentinian past significatively and with new eyes. They are political and diverse but coincide in the metaphorical transposition of a historical trauma, "es interesante subrayar la simbólica mención -y aceptación de la existencia- de un trauma político, tanto en su vertiente colectiva o nacional como en el aspecto personal o familiar," Neuman says ("Narrativa" 4).

In 1976 Clara Obligado arrives in Spain with a devastated and dialogic voice which needs to settle down in a homeSpace, or third space, and which can only be deployed in stories of globality and in-betweenness. To be a foreigner, she states, is "por un lado, una realidad dura y, por otro lado, el símbolo de una manera de estar en el mundo que es muy propia de nuestro tiempo: provisional, azarosa, descentrada" (Agraso 63). Language, Spanish language, falls us apart, you are not born an exile or a foreigner, but it sticks to your skin like a wound. El libro de los viajes equivocados is a series of intertwined stories without an explicit temporal or spatial nexus but which connect to each other and constitute a complex generic and metafictional research that comprises the history of humankind where numerous issues are confronted: executions in the dictatorship, the conflict with the mother, an aristocratic childhood or the gender troubles. Obligado lies somewhere between Piglia or Fogwill and Caparrós or Pauls. Her tone and amphibian approach, in fact her condition of displaced migrant, is closer to Neuman than to the writers of her own generation who seemed to possess absolute certainties within the homeland. However, "las generaciones nuevas se manejan en la duda, que nada tiene que ver 
con la desinformación, la resignación o el desinterés, y que permite una profundidad reflexiva particular" (Drucaroff 158). As Ana María Shua summarized it, "una de las formas que adopta la memoria (del pasado reciente) es un género que, aunque reconoce raíces en nuestra tradición, trae también una novedad muy importante: es la narrativa del horror" (qtd. in Drucaroff 296). When Obligado published Salsa, one of the first texts which fictionalized the migratory experience in Spanish literature, nobody from the academia was ready for its hemispheric excentricity so common in twentieth-century North American literary experience.

Obligado's stories show uncomfortable truths deployed from a liminal space where identity is always questioned, displacing the monolithic and central discourse of broken images and indeterminate fragments to be reordered in La muerte juega a los dados (2015), with its multiple viewpoints that the reader has to relocate in a self-fictional multiverse, or Petrarca para viajeros (2015), where the central figure is the passage, to sail adrift while living at random, a historical introspection into this century's calamities where death and prosecution get on trains which have lost all innocence or romanticism. The diasporic feeling of writers like Obligado is that of alienation, invisibility, even paralysis, which is reflected in agonic closed spaces, a continuous journeying in search for a final place, fighting against demographic indeterminacy, and finally, illness and death.

In Salsa, Obligado shows the difficulties of linguistic exile through the squizofrenic impulse to use different versions of the same language: "traduciendo siempre. Perdóname (perdoname) estoy hecha polvo (reventada), además tengo el grifo abierto (la canilla) y te oigo fatal (como la mona)," we read. "Agotador, cońo (mierda), tenía que serenarse (tranquilizarse) ya (de una buena vez) [...]. Vivía en dos planos, en dos idiomas [...]. Todo nos une, pensó Viviana, menos el idioma (2526). In Bariloche (1999), Una vez Argentina (2014) or Fractura (2018) Neuman also challenges his own bilingual self in the characters who speak different dialects of Spanish. Elena in Talking to Ourselves (2014) reflects with sarcasm on the different ways of saying and behaving in sexual intercourse:

In order not to feel inferior in the face of Ezequiel's scientific knowledge, I made a list for him of the different verbs in Spanish that describe an orgasm. In Cuba, for example, they say venirse-to draw near. I like that verb because it suggests moving towards someone. It is a verb for two. And essentially unisex. In Spain they say correrse-to run. Which implies almost the opposite. Taking off at the end, moving away from the other. It is a verb for men. In Argentina they say acabar-to end. It sounds like an order. Like a military exercise. A Peruvian woman friend calls it llegar-to arrive. Put like that, it sounds almost like utopia (and it often is). As though you were far away or needed more time. Her husband says darla-to give it. Curious. That sounds like an offering. Or, being pessimistic, like a favor done to you: here, take this. In which case it doesn't surprise me that my friend never arrives. In Guatemala they say irse-to go. A clear statement of abandonment. They need only add: after you've paid. In other countries they say terminar-to finish. Frustrating. It sounds like someone barges in and interrupts you halfway through. Here, though, perhaps we are frontier people, we say cruzar-to cross over. 
Are there places where they name women's orgasms? Where they say I'm drowning, I'm dissolving, I'm unravelling, I'm irradiating? (56)

HomeSpace and journeying are central themes, not always simply recalled or experienced in positive ways, which is especially relevant considering the childhood traumas of sexual harassment which take place within the home, as in the case of Lyuba in Los viajes equivocados, or Thien's Paula, whose "father was standing beside our bed. He was touching her hair" ("Alchemy" 75), or Anil's brother who, as Eva's brother (Subsuelo 121, 233), demanded sexual favours (Anil's Ghost 68). This liminality and intermediateness, represented by the questioning of what is real and what is unreal, is ultimately strengthened by the use of global space, as in the claustrophobic basement of del Campo's La Huésped (2016), the country house in Luján's Subsuelo, Correa-Fiz's "Una casa en las afueras," in La condición animal, in the journeying in Thien's "Dispatch" (2016) or Neuman's Talking to Ourselves. Ideas about staying, leaving and journeying, or depictions of the road trip and liminal spatiality are integrally associated with notions of home or its visible absence.

Short stories have two tales within, the explicit plot, and the secret, ellyptical and fragmentary tale, "de pronto aparece un desvío, un cambio de ritmo, algo externo; algo que está en el cuarto de al lado," says Piglia (Formas breves 127). This mysterious next room reveals an otherworldy landscape, an unresolved conflict with our liminal neighbour, the unknown immigrant next door who may reveal something unknown or uncomfortable. Narrating is an act of revealing, of foreseeing the unexpected within the familiar, the guilt of the disappeared: "todo lo que ya sucedió y todo lo que sucederá en el cercano y espantoso futuro inmediato: todo; incluso la mudez absoluta y definitiva de una madre ante lo imposible, ante lo que nadie nunca quiere que suceda," an omniscient narrator affirms in Subsuelo (236). The repetitive statement "A nadie le importa dónde aparecen los muertos" (223) in the novel recalls the dead of Anil's Ghost by Ondaatje and Fractura by Neuman, a collective memory of the disappeared which expands in concentric circles where the detection story, as Renzi in Piglia's Diaries, tries to unveil a wounded memory:

Se ha bunkerizado dentro de sí mismo [...]. Su claustrofobia es vertical [...] el margen donde flotan sus ideas y recuerdos [...]. En su condición de maniático, sabe que cada espacio posee un equilibrio secreto y cualquier desajuste puede perturbarlo [...]. Watanabe avanza como un detective que investiga el crimen cometido en su propia habitación [...]. Todas las cosas rotas tienen algo en común. Una grieta las une a su pasado. (Fractura 23-25)

Mental or physical disease in the homeSpace can be seen as a resource to question self-consciousness of our no-place in the world, a physical and psychological dislocation which, in the case of Correa-Fiz, Schweblin, del Campo or Neuman, have admittedly literary influences in Kafka, Flannery O'Connor, Sylvia Plath or Virginia Woolf. In Neuman's Talking to Ourselves Elena comes back to her noplace as a wounded carer. 
When I don't look after anyone, no one looks after me [...]. When I open the front door and hang my bag on the coat stand, I realise how big this house is going to be. I walk through its emptiness [...]. I, too, am missing here [...]. I am the only visitor and also an intruder.

There is no one here. No one in me. The person who cries, eats, has a nap, goes to the bathroom, is someone else. (85-86)

As our subjectivity is tied to otherness, self fiction and autobiography are key components in these narratives as in del Campo's nameless protagonist who cries "¿[e]s la existencia del otro lo que sostiene la propia?, ¿cuál es la terrible enfermedad que nos acecha y hace posible que normalicemos lo que interna e individualmente no resulta natural?" (La huésped 80). The use of the first person is born in confusion and ambiguity, in painful memories, in private territory. As Judith Butler asserts in Undoing Gender, "[d]espite all our differences in location and history, my guess is that it is possible to appeal for a 'we,' for all of us have some notion of what it is to have lost somebody. Loss has made a tenuous 'we' of us all" (20). Chariandy, Neuman and del Campo show us how identity is thus involved in corporeal changes, and sickness gives way to the questioning of our subjectivity to our no-place in the world, our permanent guilt at trying to live our own lives despite responsibility and family ties:

By caring for our sick person, we are protecting their present. A present in the name of a past. What am I protecting of myself? This is where the future comes in (or hurls itself out of the window). For Mario it is unconceivable. He can't even speculate about it. The future: not its prediction but the simple possibility of it. In other words, its true liberty. That is what the illness kills off before killing off the sick. (Talking to Ourselves 83)

Mental and physical disease can be menacing but triggers our thoughts towards identity processes and depict other ways of naming the narrative experience to design an effective body order, to analyse different forms of self figuration so as to educe the textual strategies, generic attributions and perceptions of the self that inform autobiographical texts: "Who counts as human? Whose lives count as lives? And, finally, what makes for a grievable life?," Butler wonders (Precarious 20). Neuman and del Campo add the fact of the pain and guilt of being a woman-carer who suffers the pain, who is demanded to stay with the sickening family, the inability of going on with her own sexual life, of escaping the chains of being female, wife or daughter. Showing the hospital documents within the fictional experiment, as with the family photographs in Running in the Family, parodies objectivity and reliability in madre mia (2017) by Florencia del Campo, who wonders whether the bed-ridden sick mother is a manipulating monster: "[l]a familia puede ser a la persona lo que un tumor al cuerpo" (171).

In Luján's Subsuelo the family is the core of evil, characters are made of loss and secrets, silences and lies. At the background is the country house, invaded by ants, where "[n]adie sabrá nunca cómo llegaron aquellas hormigas hasta allí," we read, 
“cómo y porqué se había producido esa suerte de suicidio colectivo" (127). Indeed, the metaphoric oracle of a tragic end. Or in Correa-Fiz's amphibians, "nos enfrentamos a una plaga de anuros genéticamente modificados [...] La violencia se intuía por el silencio y la exasperante lentitud de las cosas" ("Criaturas" 145-146; emphasis original) which will announce the stillborn baby, "no estamos nunca preparados para que el dolor nos manosee" ("Criaturas"159). This return to family, to parentless childhood, to childless selves, is a return to the past in multifarious forms also evident in Running in the Family, Soucouyant, Una vez Argentina, La muerte juega a los dados, or en breve cárcel; to toxic traumas as in Fractura, Fever Dream or La condición animal, to sexual encounters which come to the fore in Funny Boy or Precoz. Deadly sickness is no less prevalent in Soucouyant, Talking to Ourselves or madre mía, as articulated in the present enunciation, where mediation takes place, where collective memory pleads to restore our own scars through the Japanese art of Kintsugi, as Neuman's Fractura shows us: “'hasta qué punto un daño es reparable? ¿No valdría la pena hacer algo diferente? ¿Por qué disimular los desperfectos en sus banjos y no integrarlos en su restauración? Todas las cosas rotas, piensa, tienen algo en común. Una grieta las une a su pasado" (24-25).

Posthumanism, as the de-centering of the human, nurtured by scientific developments can be related to the persistence of social and political practices that assume or seek to re-instate the primacy of the individual even and especially in the face of death and dispossession. Sometimes those assumptions are part of a challenge to the power of governments and of warmongering and other corporate interests, which Anil's Ghost, Fractura, Fever Dream or La condición animal posit, and the very individuation through which they operate compounds the injustice that is being done, as seems the case in Salsa, Soucouyant or Funny Boy. In the last thirty years of Canadian and Argentinian hemispheric storytelling there has been a dialogue with insights drawn from a broad range of feminist, intercultural, globalized and post-colonial writing produced, a transversal discursive exchange which provides new insights towards the growing contestation of its humanist claims, "as a consequence of the re-centering of the world away from other Europe-centred paradigms" (Braidotti and Gilroy 3).

Likewise, there is a continuous rendering of the racialized and gendered body in terms of what contemporary theorists refer to as "posthuman embodiment" as underlined by Braidotti ("Contested"). How do conflicting notions of humanity and of what counts as human relate to the numerous instances of exile, dispossession, and eviction that have taken place during the last century? How do they affect our understanding of belonging to real and imagined homelands? (Braidotti and Gilroy 4). To what extent these hemispheric works open up new possibilities for a global recomposition of Humanity on fundamentally new grounds: a posthumanist cosmo-politics? Neuman's Fractura does with its globalized characters who move between Tokio, Paris, New York, Buenos Aires and Madrid. The real focus for Braidotti lies in a change of paradigm brought about by the emergence of posthuman discourses. This posthuman turn, since the 1970s, is materialist and nonfoundationalist: it marks the convergence of antihumanism with post-anthropocentrism but moves beyond them both in a more complex direction, overcoming 
the limitations of both humanism and antihumanism (Braidotti 19). Animal studies and eco-criticism have grown into rich and well-articulated fields providing the new ontological grounds for knowledge production that "include relation to organic and inorganic non-human others, scientific and technological advances, ecological and social sustainability and the multiple challenges of globalization, including poverty and structural injustice" (Braidotti 23). Accordingly, posthuman bodies "are not slaves to master discourse but emerge at nodes where bodies, bodies of discourse, and discourses of bodies intersect to foreclose any easy distinction between actor and stage, between sender/receiver, channel, code, message, context" (García Zarranz 46). Hiromi Goto's female protagonists address the potential for marginalized subjects to counteract hegemonic structures by finding power through the transgression of multiple boundaries as it is also the case in Selvadurai's Funny Boy, Harwicz's Precoz, Correa-Fiz La condición animal or Schweblin's Fever Dream. In Goto's Half World, as we read,

Melanie turned to the water once more and stared at the distant shore. Industrial cranes, with their bright orange legs and long necks, look like mechanical giraffes. In her peripheral vision she could see the crow hop closer and begin picking at its meal. Melanie's stomach grumbled. She was hungry [...] almost hungry enough to try the abundant mussels exposed on the rocks, but she knew the water was filthy with chemicals, tanker sludge and heavy metals. (17)

García Zarranz highlights the transcorporeal qualities of the scene portrayed here where the technological, the human, and the animal worlds collide, pointing to the negative, and often toxic, consequences of excessive industrialization on both human and non-human bodies (47). And this is an everyday reality for Goto's fiction, Schweblin's, Correa-Fiz's, Harwicz's, and many other lowincome populations subjected to high levels of toxic material in their work places or the cities they inhabit. These writers are thus "positioning an anti-capitalist critique against current issues such as the negative impact of economic globalization on both environmental degradation and material human bodies and other organisms" (García Zarranz 48). The same reflections can be seen in Schweblin's Fever Dream, Luján's Subsuelo, Harwicz's Precoz, Correa-Fiz's La condición animal or Neuman's Fractura. These protagonists are portrayed as collective selves to the world they live in. García Zarranz calls these bodies "phantom bodies" since, despite their hypervisible materiality, "[...] their deviance from the norm [...] reduces their agency into merely haunting presences" (49).

Rahul K. Gairola (2017) also analyses the malevolent spirits in Mootoo's Cereus Blooms at Night as "otherworldly duppies" or spectres of dissent. In a similar vein, the voice and tone, paralelled to Schweblin's David in Fever Dream, destabilize, on the surface, the very notion of a national identity as an organizing principle of citizenship, sexuality and worldliness in their fictions but, like the iceberg, we must plumb into the depths of these texts to flush out the queer and tragic spectres that circulate the narratives through persistent hauntings (Gairola 19). These posthuman bodies are contaminated, deadly, queer bodies. Goto and Mootoo, as 
Schweblin, Harwicz, Correa-Fiz or Luján do, pose a critique of how contemporary societies are populated by troubled creatures whose experiences of embodiment and corporeality are depicted in terms of lack, trauma, and fear. The potential for agency between the social norm and the embodied experience is explicit in Judith Butler's work on gender and desire,

The 'I' becomes, to a certain extent, unknowable, threatened with unviability, with becoming undone altogether, when it no longer incorporates the norm in such a way that makes this 'I' fully recognizable. There is a certain departure from the human that takes place in order to start the process of remaking the human. I may feel that without some recognizability I cannot live. But I may also feel that the terms by which I am recognized make life unlivable. This is the juncture from which critique emerges, where critique is understood as an interrogation of the terms by which life is constrained in order to open up the possibility of different modes of living. (Undoing Gender 4)

Over the last two decades Argentina's rural communities have reported skyrocketing rates of birth abnormalities, miscarriages and cancer. In the same period, genetically modified soy has blanketed the region. This is the landscape in which Samanta Schweblin's unsettling novel Fever Dream unfolds. Schweblin writes in a spare and highly impressionistic style that embraces instability: of space, identity and the reader's trust. It is a deeply transnational work, about parental love, rapacious industrial agriculture and historic trauma, whose narrative instability viscerally recreates the insecurities of life in Argentine countryside today and certainly a metonymy of worldwide agricultural crisis. Queer, in these stories, is the potentiality to produce a political critique of systems that refuse to allow certain bodies a viable form of existence. Schweblin, as Mootoo, Harwicz and Correa-Fiz, does blur the boundaries between the natural and ethereal worlds in everyday life experiences of nature, thus also interrogating the constructed boundaries between natural and unnatural social articulations of sexuality. These themes of the supernatural also emerge in real spaces, transforming into comfort zones for characters who must take refuge from the ugliness of the material world in del Campo: "Camino y con cada pisada siento que doy un martillazo. Hay que romper todo: todo está lleno de bichos, no es solo azulejos y baño. Es todo. Lleno de bichos y mierda. Esto se ha contaminado" (La Huésped 83). These characters live on and across various physical and psychological borders: "nunca entendemos el dolor del otro sino en la parte que se parece al nuestro" says the narrator in Correa-Fiz's "Lo que queda en el aire" (63).

These boundary crossings emphasize not only the multiplicity of identity, but also the decolonizing politics in the hemispheric landscape. The very definition of humanity and globality depends on both the construction and the exclusion of the non-human, the uncivilized, the savage, the animal. Huggan and Tiffin call for a revision of the Humanistic world view and conclude that "a postcolonial environmental ethic, necessitates an investigation of the category of the 'human' itself and the multiple ways in which this anthropocentric construction has been and is, complicit in racism, imperialism and colonialism". According to them, "[t]he key 
issue is no social justice without environmental justice; and without social justice -for all ecological beings- no justice at all" (10).

Braidotti, in turn, rightly pleads for affirmative politics grounded on immanent interconnections, a transnational ethics of place. What we need are embedded and embodied, relational and affective cartographies of the new power relations that are emerging from the current geopolitical and post-anthropocentric world order: class, race, gender and sexual orientations, age and able-bodiedness are more than ever significant markers of human 'normality' (36), she explains. The sites of multiple identities and histories, visible through travel, through distance from the site of erasure, call attention to the importance of geography, of place and space and the multiple transformations various bodies go through during the process of acquiring identity: "No tener cuerpo es un deseo errado. La piel, la carne cuentan; son como un palimpsesto donde se inscribe nuestra historia," narrates Aldo in "Nostalgia de la morgue" (106). These global, gothic discourses have "for some time been paired in critical invocations of the unhomely or spectral legacies of imperialism and globalization". As Sugars and Turcotte claim, "[t]his legacy, which appears in the form of unresolved memory traces and occluded histories resulting from the experience of colonial oppression, diasporic migration or national consolidation, is readily figured in the form of ghosts or monsters that 'haunt' the nation/subject from without and within" (vii).

How do we rename the horror, the violence, the silence. How do we, prisoners of a post-memory, rename the others, "¿quién sino ellos, los poetas disidentes que luchaban por la revolución, eran los fantasmas futuros que se agitaban en el brocal de la puta noche? Les habían tendido trampas, los habían pescado uno a uno y torturado hasta la confesión. La mayoría estaban ya muertos, desaparecidos" ("Leviatán” 139). Neuman's Una vez Argentina provokes an exceptional event in the development of the new Argentinian narrative, inasmuch as it reconstructs the narrator's historical memory and recovers the certainty that there was a past. In the opinion of Drucaroff, "lo que acá se logra construir con autenticidad es lo que resulta de veras genuino, porque sí se ha transmitido de la vieja a la nueva generación: el terror [..] [l]o siniestro irrumpe y con él, la posibilidad de que nada sea como nos decimos que es, sino como tememos recónditamente" (310). The truths and lies, the secrets and guilt, the injustice of having to rename what has been stolen from us, our family history. Painfully enough, Neuman rewrites and edits Una vez Argentina ten years later to add his aunt's Silvia's real account before emigrating to Spain,

Durante las sesiones de tormento, Silvia había averiguado cosas de su cuerpo que hubiera preferido no saber. Una de las más inesperadas había sido su capacidad para dañarse a sí misma: no siempre las descargas de la picana le habían causado más dolor que los golpes de su propia cabeza y su propia espalda contra la superficie donde la maniataban. En algún momento esto le había parecido revelador, pero no supo bien de qué [...]. Mientras a mi tía la torturaban, a su esposo lo habían obligado a mirar. Y, una vez tras otra, le habían preguntado cómo demonios era posible que un alemán le hubiese hecho un hijo a una judía. (28-29) 
This is the new way of naming our scars, haunted by global space and time, without any territorial prejudice. In Bariloche, for instance, a blurred subject allegorizes a common burial in cosmopolitan non-places, the junkspace where the disappeared cry for justice,

La vista se le perdía en un horizonte de fragmentos extrañamente organizados, de millones de cabezas asomadas desde la tierra hacia la fría noche, buscando algo de oxígeno. A Demetrio le costaba entender, Dios santo, cómo podía haber tanta, tanta mierda, mejor dicho, más que moverse como criaturas individuales, los desperdicios lo hacían con tendencia a fusionarse, era tan uniforme todo, el nylon, la mierda, el silencio [...]. La Mierda Única, un mar de ahogados. (166-167)

This new war through renaming has made these authors express a painful narrative construct, in the killing ants in Luján's Subsuelo, the soya fields in Schweblin's Fever Dream, or Alzheimer disease in Soucouyant and Siete casas vacias, the breathless and stinky room in Flor del Campo's La huésped, in the reconstruction of collective memory through the kintsugi art in Neuman's Fractura, in the unable carers in Neuman's Talking to Ourselves, Chariandy's Soucouyant or del Campo's madre mía, in Correa Fiz's statement that nothing is what it seems: "Se asomó al espejo del agua y una arcada le hizo verificar la pesadilla: los peces estaban disputándose un trozo de carne. En el centro del pozo resplandecía un brazo blanco. Vomitó, cayó de espaldas, se fisuró un tobillo. Dijo que creía haber perdido el conocimiento hasta la medianoche" ("Leviatán" 141), similarly, in Harwicz’s narrator's words: "Me despierto con la boca abierta como el pato cuando le sacan el hígado para el foie gras. Mi cuerpo está acá, mi cabeza más allá, afuera una cosa golpea como una arcada (Precoz 7). HomeSpace itself serves as a repository of the past and itself cobwebbed memories even as it is materially, and territorially, anchored in the present: "Adentro el fuego, afuera la nieve, el cuerpo adentro, la mirada afuera" (La Huésped 89).

The obscure area these writers are exploring is desperation at all levels, material and sexual, through a new way of naming the inherited past, a post-memory, which generates an aesthetics which moves and scandalizes:

Es preocupante ser patética en un país donde no hablan tu idioma [...]. Estoy sola y enterrada en mi patetismo [...]. No puedo más, me lo repito una y otra vez en la negrura del búnker, en el silencio de la nieve, mientras intento conciliar el sueño con sabor a óxido que me dejó la cena. Todo se está oxidando en este sitio [...]. Ellos habitan en estas manchas; las llevan en la piel como marcas naturales. ( $\mathrm{La}$ Huésped 57, 60)

These writers destabilize the physical world shattering the notion of safe space. Identity is thus destabilized in a profound way: "[s]i quieres sobrevivir deshazte de tu identidad" (Thúy 24). Our space is haunted by uncanny characters, ghostlike figures of our past. We live on land we cannot trust: families are destroyed, motherhood is frustrated, an aura of psychological menace and otherworldly reality surrounds us. As the pace of cultural globalization accelerates, the hemispheric 
literary studies have undergone a dramatic and ethical transformation in Canadian and Argentinian narratives. This ethical and transnational turn that we have been witnessing in the last twenty years has come to dominate the contemporary global fiction and reshaped it as what can be considered the New American Narrative.

Reviews sent to author: 14 October 2018 Revised paper accepted for publication: 12 November 2018 


\section{WORKS CITED}

Agraso, Aida R. "Entrevista a Clara Obligado, autora de 'El libro de los viajes equivocados”, Diario de Cádiz. Biblioteca-entrevista (23 Jan. 2012). 2 Aug. 2017. Web <http://www.claraobligado.com/Archivos/DiarioCadiz.pdf>.

Bhabha, Homi. The Location of Culture. London: Routledge, 1994. Print.

Braidotti, Rosi and Paul Gilroy. "Introduction.” Conflicting Humanities. Eds. Rosi Braidotti \& Paul Gilroy. London: Bloomsbury, 2016. 1-7. Print.

Braidotti, Rosi and Paul Gilroy. "The Contested Posthumanities." Conflicting Humanities. Eds. Rosi Braidotti \& Paul Gilroy. London: Bloomsbury, 2016. 9-45. Print.

Brydon, Diana. "Introduction. Canada, Brazil and Beyond: Extending the Dialogue." Canada and Beyond: A Journal of Canadian Literary and Cultural Studies. 6 (2017): 3-8. Print.

Butler, Judith. Precarious Life: The Powers of Mourning and Violence. London: Verso, 2004. Print.

Butler, Judith. Undoing Gender. New York: Routledge, 2004. Print.

Chariandy, David. Soucouyant. 2007. Vancouver: Arsenal Pulp Press, 2008. Print.

Correa-Fiz, Valeria. “Criaturas.” La condición animal. Madrid: Páginas de Espuma, 2016. 143161. Print.

Correa-Fiz, Valeria. "Leviatán.” La condición animal. Madrid: Páginas de Espuma, 2016. 135142. Print.

Correa-Fiz, Valeria. "Lo que queda en el aire." La condición animal. Madrid: Páginas de Espuma, 2016. 55-66. Print.

Correa-Fiz, Valeria. "Nostalgia de la morgue." La condición animal. Madrid: Páginas de Espuma, 2016. 87-226. Print.

Darias-Beautell, Eva. "Haunted/Wanted in Jen Sookfong Lee's The End of East: Canada's Cultural Memory Beyond Nostalgia." Canadian Literature and Cultural Memory. Eds. Cynthia Sugars and Eleanor Ty. Ontario: OUP, 2014. 402-414. Print.

Del Campo, Florencia. La huésped. Barcelona: Base, 2016. Print.

Del Campo, Florencia. madre mía. Barcelona: Caballo de Troya, 2017. Print.

Derrida, Jacques. Specters of Marx. 1993. London: Routledge, 1994. Print.

DíAz, Junot. La maravillosa vida breve de Oscar Wao. Barcelona: Mondadori, 2008. Print.

Drucaroff, Elsa. Los prisioneros de la torre: politica, relatos y jóvenes en la postdictadura. Buenos Aires: Emecé, 2011. Print.

Foster, David William. “The Argentine 1960s.” Works and Days. $39 / 40$ (2002): 121-140. Print.

Fresán, Rodrigo. Historia argentina. 1991. Barcelona: Penguin Random House, 2017. Print.

Gairola, Rahul K. "Bastardly Duppies and Dastardly Dykes: Queer Sexuality and the Supernatural in Michelle Cliff's Abeng and Shani Mootoo's Cereus Blooms at Night." Wagadu: A Journal of Transnational Women's and Gender Studies 18 (Winter 2017): 19-54. Print.

García-Zarranz, Libe. Queer TransCanadian Women's Writing in the 21st Century: Assembling a New Cross-Border Ethic. PhD. Thesis. University of Alberta (Fall 2013). Print.

Gilroy, Paul. The Black Atlantic: Modernity and Double Consciousness. Cambridge: Harvard UP, 1993. Print. 
Goтo, Hiromi. Chorus of Mushrooms. Edmonton: NeWest, 1994. Print.

Goто, Hiromi. Half World. Canada: Penguin, 2009. Print.

Harwicz, Ariana. Precoz. Barcelona: Rata Books, 2016. Print.

Huggan, Graham. The Postcolonial Exotic: Marketing the Margins. New York: Routledge, 2001. Print.

Huggan, Graham and Helen Tiffin. Postcolonial Ecocriticism. Literature, Animals, Environment. New York: Routledge, 2015. Print.

JAY, Paul. Global Matters: The Transnational Turn in Literary Studies. New York: Cornell UP, 2010. Print.

Lubarsky, Alexander H. “Argentine 'Dirty War': Human Rights Law and Literature.” Theses and Dissertations. San Francisco: Golden Gate University School of Law, 1997. 11 April 2018. Web $<$ https://digitalcommons.law.ggu.edu/cgi/viewcontent.cgi?article=1035\&context=theses $>$.

Luján, Marcelo. Subsuelo. Madrid: Salto de Página, 2016. Print.

Mishra, Vijay. The Literature of the Indian Diaspora: Theorizing the Diasporic Imaginary. London: Routledge, 2007. Print.

Mistry, Rohinton. 1992. Tales from Firozsha Baag. Toronto: McClelland \& Stewart, 1994. Print.

Molloy, Sylvia. en breve cárcel. 1981. Buenos Aires: FCE, 2011. Print.

Моотоo, Shani. Cereus Blooms at Night. Toronto: McClelland \& Stewart, 1998. Print.

Neuman, Andrés. "La sociedad hispanoamericana y sus proyecciones literarias." II mesa redonda del Instituto Cervantes de Múnich. Renacimiento: Revista de Literatura. $47 / 50$ (2005): 132-48. Print.

Neuman, Andrés. “La narrativa breve argentina desde 1983: ¿̨hay política después del cuento?” Ínsula: revista de letras y ciencias humanas. 711 (2006): 5-11. Print.

Neuman, Andrés. Cómo viajar sin ver (Latinoamérica en tránsito). Barcelona: Alfaguara, 2010. Print.

Neuman, Andrés. Hablar solos. Barcelona: Alfaguara, 2012. Print.

Neuman, Andrés. "Las Orillas.” Década. 2008. Barcelona: Acantilado, 2012. 73. Print.

Neuman, Andrés. Barbarismos. Madrid: Páginas de Espuma, 2014. Print.

Neuman, Andrés. Talking to Ourselves. 2012. Trans. Nick Caistor and Lorenza García. London: Pushkin Press, 2014. Print.

Neuman, Andrés. Una vez Argentina. 2003. Barcelona: Alfaguara, 2014. Print.

Neuman, Andrés. Bariloche. 1999. Barcelona: Alfaguara, 2015. Print.

Neuman, Andrés. How to Travel Without Seeing. 2010. Trans. Jeffrey Lawrence. New York: Restless Books, 2016. Print.

Neuman, Andrés. La vida en las ventanas. 2002. Barcelona: Alfaguara, 2016. Print.

Neuman, Andrés. Fractura. Barcelona: Alfaguara, 2018. Print.

Neuman, Andrés. Fracture. Trans. Nick Caistor and Lorenza García. London: Granta, 2019. Print.

Noguerol Jiménez, Francisca. "Literatura argentina trasterrada y dictadura: versiones desde el margen.” DT 13 (2012): 1-22. Print.

Obligado, Clara. Salsa. Barcelona: Plaza \& Janés, 2002. Print.

Obligado, Clara. Las otras vidas. Madrid: Páginas de Espuma, 2005. Print. 
Obligado, Clara. El libro de los viajes equivocados. Madrid: Páginas de Espuma, 2011. Print.

Obligado, Clara. La muerte juega a los dados. Madrid: Páginas de Espuma, 2015. Print.

Obligado, Clara. Petrarca para viajeros. Valencia: PRE-TEXTOS, 2015. Print.

Ondaatje, Michael. Running in the Family. 1982. London: Victor Gollancz, 1983. Print.

Ondaatje, Michael. Anil's Ghost. Toronto: McClelland \& Stewart, 2000. Print.

Piglia, Ricardo. Formas breves. 2000. Barcelona: Anagrama, 2015. Print.

Piglia, Ricardo. Los diarios de Emilio Renzi: años de formación. Barcelona: Anagrama, 2015.Print.

Piglia, Ricardo. Los diarios de Emilio Renzi. Años felices. Barcelona: Anagrama, 2016. Print.

Schweblin, Samanta. Distancia de rescate. Barcelona: Random House, 2014. Print.

Schweblin, Samanta. Siete casas vacias. Madrid: Páginas de Espuma, 2015. Print.

Schweblin, Samanta. Fever Dream. 2014. Trans. Megan McDowell. New York: Riverhead Books, 2017. Print.

Selvadurai, Shyam. 1994. Funny Boy. London: Vintage, 1995. Print.

Siemerling, Winfried. Discoveries of the Other: Alterity in the Work of Leonard Cohen, Hubert Aquin, Michael Ondaatje \& Nicole Brossard. Toronto: U of Toronto P, 1994. Print.

Siemerling, Winfried \& Sarah Phillips Casteel. "Introduction." Canada and Its Americas: Transnational Navigations. Eds. Winfried Siemerling \& Sarah Phillips Casteel. Montreal: McGillQueen's UP, 2010. 3-28. Print.

Sugars, Cynthia. "World Famous Across Canada: National Identity in the Global Village." Global Fissures: Postcolonial Fusions. Eds. Clara A.B. Joseph and Janet Wilson. New York: Rodopi, 2006. 79-101. Print.

Sugars, Cynthia \& Eleanor Ty. "Introduction: Thinking Beyond Nostalgia: Canadian Literature and Cultural Memory." Canadian Literature and Cultural Memory. Eds. Cynthia Sugars and Eleanor Ty. Ontario: OUP, 2014. 1-19. Print.

Sugars, Cynthia \& Gerry Turcotte. "Introduction." Unsettled Remains: Canadian Literature and the Postcolonial Gothic. Eds. Cynthia Sugars and Gerry Turcotte. Ontario: Wilfrid Laurier UP, 2009. vii-xxvi. Print.

Thien, Madeleine. 2001. “Alchemy.” Simple Recipes. 2001. Canada: Vintage, 2016. 55-76. Print.

Thien, Madeleine. “Dispatch.” Simple Recipes. 2001. Canada: Vintage, 2016. 77-98. Print.

Thúy, Kim. Mân. 2013. Trans. Laura Salas Rodríguez. Cáceres: Periférica, 2016. Print.

Vassanji, M.G. Ed. A Meeting of Streams: South Asian Canadian Literature. Toronto: TSAR, 1985. Print.

Verduyn, Christl. Literary Pluralities.Ontario: Broadview Press, 1998. Print.

WARLEY, Linda. "Locating the Subject of Post-Colonial Autobiography." Kunapipi 15.1 (1993): 22-31. Print.

Zorc-Maver, Darja and Igor Maver. "Guillermo Verdechia and the frontera in Contemporary Canadian Diasporic Writing.” Acta Literaria 43 (2011): 119-126. Print. 
